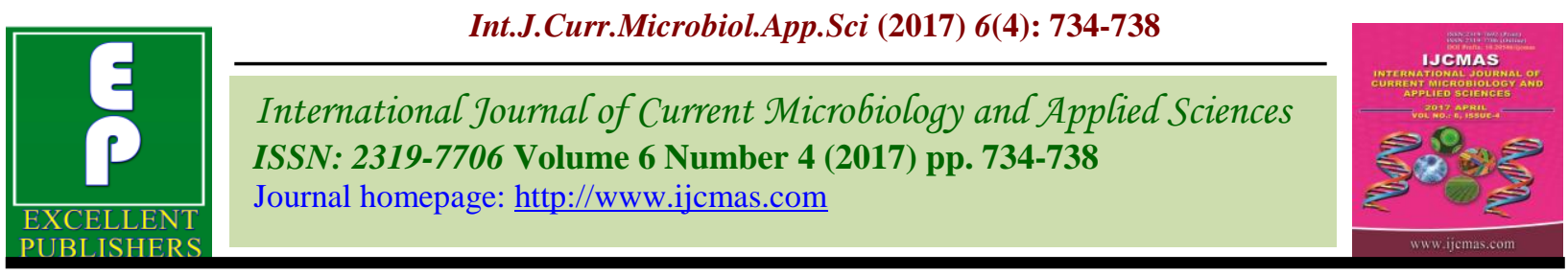

Original Research Article

https://doi.org/10.20546/ijcmas.2017.604.090

\title{
Evaluation of Rice Varieties for Yield under Organic Farming in Tarai Region of Uttarakhand, India
}

\author{
D.K. Singh*, Shilpi Gupta, Gangadhar Nanda, Yogesh Sharma, \\ V.V. Singh and Dipti Bisarya
}

\author{
Department of Agronomy, G.B. Pant University of Agriculture and Technology, \\ Pantnagar, Uttarakhand- 263 145, India \\ *Corresponding author
}

\begin{abstract}
A B S T R A C T
Keywords

Organic farming,

Rice varieties,

Tarai region,

Uptake, Yield.

Article Info

Accepted:

06 March 2017

Available Online:

10 April 2017

Performance of modern cultivars in terms of yield under organic farming differs from that of conventional system. As the demand for organic rice is increasing, so to maintain high productivity, there is a need to evaluate modern high yielding rice varieties under organic farming systems. Field experiments were carried out using randomized complete block design involving fourteen rice (Oryza sativa L.) varieties including seven coarse and seven fine grain types with three replications under organic farming systems for three years (2013-2015). Results of the study revealed that higher yield attributes viz. grain weight panicle $^{-1}$, 1000-grain weight, grain and straw yield as well as $\mathrm{N}, \mathrm{P}$ and $\mathrm{K}$ uptake were recorded with coarse grain rice variety NDR-359. Among the fine grain rice varieties, Pant basmati-1 recorded higher grain yield as well as N, P, K and S uptake. So, coarse grain rice variety NDR-359 and fine grain rice variety Pant basmati-1 can be recommended under organic rice production in Tarai region of Uttarakhand (India).
\end{abstract}

\section{Introduction}

Organic farming is gaining momentum during recent times due to awareness of people towards environment and food safety. Organic agriculture comes across as a promising opportunity for farmers of Uttarakhand, especially the tribals, small and marginal farmers in the rainfed region or regions where traditional low input farming is practiced (Singh et al., 2017b). Rice is the staple food crop of world after wheat and the demand of organic rice is increasing due to its export potential. Basmati rice is regarded as the king of rice and is cultivated for its subtle aroma, long grain and delicious taste. It is priced high owing to better organoleptic quality characteristics but its demand is very high in other countries (Singh et al., 2017a).

There is always a continuous search for agronomic improvement to optimize farming system under organic farming and needs suitable varieties to realise its potential (Kokare et al., 2014). Despite the potential benefits of organic farming in terms of better soil health and quality of produce, maintenance of high yields is one of major challenge under organic farming systems (Tilman et al., 2002). Modern cultivars have been selected by plant breeders under conventional systems and they may not 
perform well under organic farming systems where they are grown in stressed environment without addition of external inputs that is entirely different to those in which they were selected (Ceccarelli, 1996; Murphy et al., 2007). So, there is a need to select varieties for organic farming which is believed as a stressed environment as crops are not supplied with chemicals for either supplying nutrients or to protect the crop from pests and diseases. During recent time coarse grain varieties viz. PD-4, IR-64, Pusa-44, PD-18, PD-19, NDR-359 and UPR-3425-11-1-1 and fine grain rice varieties viz. Taraori, Type-3, Pusa Basmati-1, Pusa-1121, Pant Basmati-1, UPR-3488621 and UPR-3506-7-1-1 are grown widely under different ecosystems due to their high yields under intensive cultivation practices. Therefore, these varieties were chosen to evaluate their performance under organic farming in this study. Our results will make farmers informed about the choices of high yielding varieties (both coarse and fine grain) for organic rice production in Tarai region of Uttarakhand.

\section{Materials and Methods}

Field experiments were carried out at Seed Production Centre of G.B. Pant University of Agriculture and Technology, Uttarakhand during wet seasons of 2013 to 2015 in the mollisols of Tarai region of Uttarakhand. The soil of the experimental site was silty- loam with $\mathrm{pH}$ : 7.2 ; electrical conductivity: 0.38 $\mathrm{dS} / \mathrm{m}$; high in organic carbon $(1.01 \%)$, high in available $\mathrm{N}(340 \mathrm{~kg} / \mathrm{ha})$ and available $\mathrm{P}$ (31.7 kg/ha), medium in available $\mathrm{K}(210$ $\mathrm{kg} / \mathrm{ha}$ ) and high in available $\mathrm{S}(30.8 \mathrm{~kg} / \mathrm{ha})$. The experiment was set up in randomized block design with seven coarse grains rice varieties viz. PD-4, IR-64, Pusa-44, PD-18, PD-19, NDR-359, UPR-3425-11-1-1 and seven fine grain rice varieties viz. Taraori, Type-3, Pusa Basmati-1, Pusa-1121, Pant Basmati-1，UPR-3488621，UPR-3506-7-1-1 which were replicated thrice. Green manuring with Pant Sesbania-1 was done prior to basmati rice cultivation usually in first fortnight of May in all the three years and incorporated in soil at 50-55 days after sowing. Twenty to twenty-five days old seedlings were transplanted in a puddled field at $20 \times 10 \mathrm{~cm}$ spacing with one seedling per hill in the experimental plot of $7 \mathrm{mx} 3 \mathrm{~m}$ in size usually in second fortnight of June in all the three years. All necessary precautions were taken to maintain uniform plant population in each treatment per replication. Observations were recorded and the data was subjected to statistical analysis. The level of significance was tested at 5 per cent using $\mathrm{F}$ table value given by Cochran and Cox (1966). Recommended dose of nutrients for different rice varieties were met by green manuring and vermicompost @12t/ha. To control weeds, two hand weedings were done at 20 days after transplanting (DAT) and 40 DAT. To control the insects mainly stem borer, trichocards (1 card per acre area; 5 releases), pheromone traps (20 traps/ ha at $20 \times 25 \mathrm{~m}$ distance) and cow urine $(10 \%)$ mixed with neem oil @ 125 $\mathrm{mL} / \mathrm{L}$ were used after 15 days of transplanting and 4-5 sprays were done at 15 days interval. To control the diseases, seed treatment, soil and foliar application of Trichoderma spp. and Pseudomonas spp. were done. Observations were recorded on yield attributes of ten randomly selected plants in each replication. Grain and straw yield were recorded at harvesting. Nutrient content in both grain and straw were worked out following standard procedures and respective uptakes were calculated using grain and straw yield of each variety as follows:

Nutrient uptake $(\mathrm{N}, \mathrm{P}, \mathrm{K}$ and $\mathrm{S})=$ Nutrient uptake by grain + Nutrient uptake by straw

Nutrient uptake by grain/straw $\left(\mathrm{kg} \mathrm{ha}^{-1}\right)=$ Grain yield/ straw yield $\left(\mathrm{kg} \mathrm{ha}^{-1}\right) \times$ grain/straw nutrient content (\%) 


\section{Results and Discussion}

\section{Yield attributes, yield and harvest index}

Effective tillers $\mathrm{m}^{-2}$, grain weight panicle $\mathrm{e}^{-1}$, 1000 grain weight, grain yield, straw yield and harvest index were significantly influenced by rice varieties. Maximum number of effective tillers $\mathrm{m}^{-2}$ was registered with rice variety Pusa- 44 which significantly higher than others except variety PD-118, NDR-359, UPR-3425-11-1-1, PD-19 and Pant Basmati-1 which were statistically at par. In general coarse varieties have higher grain weight panicle $^{-1}, 1000$ grain weight and produced more grain and straw yield than fine grain varieties. Variety NDR-359 recorded highest grain weight panicle ${ }^{-1}$ which was significantly greater than other varieties tested except variety UPR-3425-11-1-1 which was statistically at par. Maximum value of 1000 grain weight was observed with variety NDR359 which was statistically comparable with varieties UPR-3425-11-1-1 and PD-19. Highest grain yield was recorded with variety NDR-359 (6069 $\left.\mathrm{kg} \quad \mathrm{ha}^{-1}\right)$ which was significantly higher than other coarse and fine grain varieties except coarse grain varieties PD-18, PUSA-44 and PD-19 which were statistically at par. Among the fine grain varieties, Pant basmati-1 recorded maximum grain yield and was significantly superior over all other fine grain varieties. Highest straw yield $\left(6690 \mathrm{~kg} \mathrm{ha}^{-1}\right)$ was observed in variety NDR-359 which was statistically at par with variety PD-18, PD-19 and UPR3425-11-1-1 which were statistically at par. Among the fine grain varieties, maximum grain yield was recorded with variety Taraori which was significantly superior over all other fine grain varieties except variety Pusa Basmati-1 which were at par with each other. Iannucci and Codianni (2016) screened durum wheat varieties for conventional and low input organic conditions based on variability in yield attributes and yield. Layek et al., (2016) screened maize varieties suitable for organic production system. The differences observed in yield attributes and yield of rice varieties attributed to the genetic character as well as their adaptation potential under low input organic conditions. Higher values for yield attributes with variety NDR-359 could be due to better growth and translocation of photosynthates to reproductive parts. Higher grain weight panicle ${ }^{-1}$ and 1000 grain weight might have resulted in higher grain yield of NDR-359.

Nitrogen, phosphorus, potassium and sulphur uptake

Nitrogen, phosphorus, potassium and sulphur uptake by rice varied significantly due to varieties. Nitrogen, phosphorus, potassium and sulphur uptake by fine grain rice varieties were lesser than coarse grain rice varieties. Highest nitrogen uptake by rice was recorded with variety NDR-359 which was statistically comparable with PD-18, PD-19, UPR-342511-1-1, Pusa-44 and PD-4. Highest phosphorus uptake by rice was recorded with variety NDR-359 which was statistically comparable with PD-19, PD-18 and UPR3425-11-1-1. Highest potassium uptake by rice was recorded with variety NDR-359 which was statistically comparable with PD18, UPR-3425-11-1-1, PD-19, Pusa-44 and IR-64. Highest sulphur uptake by rice was recorded with variety PD-18 which was statistically comparable with PD-19 and NDR-359. The nutrient uptake is a function of nutrient content and yield (grain and straw).

Moreover, nutrient content is dependent upon various factors like nutrient acquisition characteristics of the variety, root characteristics and secretion of root exudates to favour microbial growth for making the nutrient available in the rhizosphere. The variety NDR-359 produced higher grain and straw yield than rest of the varieties tested, so could have led to higher uptake of N, P and K. 
Table.1 Yield attributes, yield and N P K and S uptakes of coarse and fine grain rice varieties under organic farming (data pooled over 3 years)

\begin{tabular}{|c|c|c|c|c|c|c|c|c|c|c|}
\hline Varieties & $\begin{array}{l}\text { Effective } \\
{\text { tillers } \mathrm{m}^{-2}}^{-2}\end{array}$ & $\begin{array}{c}\text { Grain wt. } \\
\text { Panicle }^{-1} \\
(\mathrm{~g})\end{array}$ & $\begin{array}{c}1000 \\
\text { grain wt. } \\
\text { (g) }\end{array}$ & $\begin{array}{l}\text { Grain yield } \\
\quad\left(\mathrm{kg} \mathrm{ha}^{-1}\right)\end{array}$ & $\begin{array}{c}\text { Straw } \\
\text { yield } \\
\left(\mathrm{kg} \mathrm{ha}^{-1}\right)\end{array}$ & $\begin{array}{c}\text { Harvest } \\
\text { index }\end{array}$ & $\begin{array}{l}\text { N uptake } \\
\left(\mathrm{kg} \mathrm{ha}^{-1}\right)\end{array}$ & $\begin{array}{l}\text { P uptake } \\
\left(\mathrm{kg} \mathrm{ha}^{-1}\right)\end{array}$ & $\begin{array}{c}\text { K uptake } \\
\left(\mathrm{kg} \mathrm{ha}^{-1}\right)\end{array}$ & $\begin{array}{l}\text { S uptake } \\
\left(\mathrm{kg} \mathrm{ha}^{-1}\right)\end{array}$ \\
\hline \multicolumn{11}{|l|}{ Coarse grain } \\
\hline PD-4 & 265 & 2.23 & 28.70 & 5256 & 6047 & 47.01 & 97.48 & 23.88 & 135.38 & 18.67 \\
\hline IR-64 & 273 & 2.30 & 27.28 & 5301 & 6088 & 47.11 & 94.64 & 22.56 & 140.11 & 15.32 \\
\hline Pusa-44 & 290 & 2.57 & 27.99 & 5708 & 6281 & 47.96 & 98.29 & 25.59 & 147.53 & 19.14 \\
\hline PD-18 & 285 & 2.49 & 28.67 & 5829 & 6432 & 49.75 & 102.31 & 26.9 & 157.48 & 24.08 \\
\hline PD-19 & 279 & 2.51 & 29.41 & 5672 & 6424 & 46.16 & 101.93 & 27.87 & 150.36 & 23.36 \\
\hline NDR-359 & 281 & 2.97 & 30.43 & 6069 & 6690 & 47.77 & 104.80 & 28.07 & 160.71 & 22.73 \\
\hline UPR-3425-11-1-1 & 279 & 2.71 & 29.51 & 5555 & 6347 & 47.24 & 99.47 & 26.7 & 151.53 & 19.10 \\
\hline \multicolumn{11}{|l|}{ Fine grain } \\
\hline Taraori & 237 & 1.56 & 22.65 & 2694 & 5300 & 33.65 & 56.95 & 16.77 & 108.77 & 14.14 \\
\hline Type-3 & 251 & 1.65 & 24.71 & 3235 & 4928 & 39.73 & 68.05 & 18.08 & 108.29 & 12.66 \\
\hline Pusa Basmati-1 & 261 & 1.65 & 23.79 & 3482 & 4799 & 42.35 & 68.13 & 20.48 & 106.00 & 12.00 \\
\hline Pusa-1121 & 265 & 1.78 & 24.51 & 4006 & 4980 & 44.74 & 77.21 & 21.47 & 123.92 & 12.68 \\
\hline Pant Basmati-1 & 275 & 1.90 & 24.96 & 4444 & 5299 & 45.65 & 87.76 & 21.75 & 126.93 & 15.89 \\
\hline UPR-3488621 & 269 & 1.96 & 25.58 & 3989 & 4886 & 44.63 & 69.07 & 17.61 & 110.54 & 12.41 \\
\hline UPR-3506-7-1-1 & 268 & 1.84 & 24.95 & 3891 & 4892 & 44.66 & 66.33 & 19.5 & 108.90 & 11.95 \\
\hline $\mathrm{SEm} \pm$ & 5.97 & 0.1 & 0.55 & 146.9 & 129.2 & 0.91 & 3.38 & 1.2 & 8.12 & 1.73 \\
\hline $\mathrm{CD}(\mathrm{P}=0.05)$ & 16.8 & 0.28 & 1.54 & 413.6 & 363.7 & 2.57 & 9.52 & 3.37 & 22.86 & 4.88 \\
\hline
\end{tabular}


Based on three years experiment it can be concluded that coarse grain rice variety NDR359 and fine grain rice variety Pant Basmati-1 can be recommended for organic rice production to get higher yields under Tarai region of Uttarakhand, India.

\section{Acknowledgement}

We gratefully acknowledge the support of ICAR- Indian Institute of Farming Systems Research, Uttar Pradesh for the financial assistance under Network Project on Organic Farming (NPOF) and Directorate of Experiment Station, G.B. Pant University of Agriculture and Technology, Pantnagar for providing facilities to conduct the experiment.

\section{References}

Ceccarelli, S.S. 1996. Adaptation to low/high input cultivation. Euphytica, 92: 203214.

Cochran, W.G. and Cox, G.M. 1966. Experimental design. $2^{\text {nd }}$ Ed. John Wiley and Sons, Inc., New York.

Iannucci, A. and Codianni, P. 2016. Effects of conventional and organic farming systems on bio-agronomic and quality traits of durum wheat under Mediterranean conditions. Australian J. Crop Sci., 10(8): 1083-1091.

Kokare, A., Legzdina, L., Beinarovica, I., Maliepaard, C., Niks, R.E., van Bueren, E.T.L. 2012. Performance of spring barley (Hordeum vulgare) varieties under organic and conventional conditions. Euphytica, 197(2): 279-293. DOI 10.1007/s10681-014-1066-8.

Layek, J., Ramakrushna, G.I., Suting, D., Ngangom, B., Krishnappa, R., De, U., Das, A. 2016. Evaluation of maize cultivars for their suitability under organic production system in North Eastern hill region of India. Indian J. Hill Farming, 29(2): 19-24.

Murphy, K.M., Campbell, K.G., Lyon, S.R. and Jones, S.S. 2007. Evidence of varietal adaptation to organic farming systems. Field Crops Res., 102: 172177.

Singh, D.K., Akhtar, Z., Gupta, S., Srivastava A. and Chakraborty, M. 2017a. Production strategies of organic basmati rice in Tarai region of Uttarakhand, India. Organic Agri., 7(1): 21-30. DOI 10.1007/s13165-015-0143-1.

Singh, D.K., Gupta Shilpi., Sharma, Y. and Singh, V.V. 2017b. Organic farming: Way for social and nutritional security of small and marginal farmers of Uttarakhand. In: Sovenier and abstracts of International conference on technological advancement for sustainable agriculture and rural development held during Feb. 20-22, 2017, pp104-105.

Tilman, D., Cassman, K.G., Matson, P.A., Naylor, R. and Polasky, S. 2002. Agricultural sustainability and intensive production practices. Nature, 418: 671677.

\section{How to cite this article:}

Singh, D.K., Shilpi Gupta, Gangadhar Nanda, Yogesh Sharma, V.V. Singh and Dipti Bisarya. 2017. Evaluation of Rice Varieties for Yield under Organic Farming in Tarai Region of Uttarakhand, India. Int.J.Curr.Microbiol.App.Sci. 6(4): 734-738.

doi: https://doi.org/10.20546/ijcmas.2017.604.090 